\title{
ÁGAPRÍTÓ BERENDEZÉS KÉSZÍTÉSE ÉS KIVITELEZÉSE
}

\section{DESIGN OF A WOOD CUTTING MACHINE}

\author{
Hodgyai Norbert, ${ }^{1}$ Gergely Attila ${ }^{2}$ \\ Sapientia Erdélyi Magyar Tudományegyetem, Marosvásárhelyi Kar, Marosvásárhely, Románia \\ ${ }^{1}$ hodgyainorbi@gmail.com \\ ${ }^{2}$ agergely@ms.sapientia.ro
}

\begin{abstract}
The price of firewood has increased substantially in the last couple of years due to the high volume of expert. The branches and smaller diameter pieces are considered leftovers and are not exportable, however they are suitable as firewood. Chainsaws are used to cut the larger diameter wood, but this way is not efficient to cut up branches and smaller diameter wood piece. In this paper we present the structure, the working principle and the 3D model of a machine that can be used to chop smaller diameter wood branches in a simple and efficient way.
\end{abstract}

Keywords: kinematic chain, branch chopping, wood cutting, design, 3D modeling.

\section{Összefoglalás}

A nagymértékű erdőkitermelés és exportálás miatt hazánkban a tüzelőfa árak jelentősen emelkedtek az utóbbi években. Az erdőkitermelésben az ágak és kisebb átmérőjü fák hulladékként jelennek meg, viszont tüzelőanyagként használhatók. Azonban ezek láncfürésszel vagy körfürésszel való darabolása nem költséghatékony. A dolgozatban egy olyan gép tervezését mutatjuk be, amellyel gyorsan és egyszerüen elvégezhetjük az ágak és kisebb átmérőjű fák darabolását. A feldarabolt faanyagot szilárd tüzelésű kazánok táplálására használhatjuk.

Kulcsszavak: kinematikai lánc, ágdarabolás, tervezés, 3D modellezés.

\section{Bevezetés}

A megvásárolt tüzelőanyag feldarabolását általában körfürésszel és láncfürésszel végzik. Kis átmérőjű és szabálytalan formájú ágak feldarabolása ezekkel az eszközökkel nem hatékony. Az utóbbi években különböző típusú daráló és aprító gépek jelentek meg a piacon amelyek segítségével gyorsan és kevés energia befektetéssel elvégezhető a favágás.

A darálógépek nagyméretű forgácsokra (2-4 cm) vágják az ágakat, amelyeket általában zsákokban tárolnak. Az eljárás energiaigényes és a zsákolt termék tárolása különleges feltételeket igényel., amennyiben szilárd tüzelésű kazánokban akarjuk hasznosítani, mivel a darált forgácsban levő nedvesség károsíthatja a terméket, ha a szellőzés nem megfelelően a tárolás idején, ezért ez a megoldás inkább a biomassza készítéséhez alkalmas. Az aprítógépek nagyméretű (10-20 cm hoszszúságú) darabokra vágják az ágakat, melynek tárolása ezáltal egyszerübbé válik. A darabokat nem szükséges felhasogatni, mivel elég rövidek ahhoz, hogy kiszáradjanak. Egy másik előnye a darabolásnak, hogy jóval kisebb az energiaigénye, hiszen amíg a darálóknál a forgácsvastagság kisebb, mint egy centiméter, a darabolóknál ez a vastagság tulajdonképpen a levágott fadarab hosszát jelenti. Több típusú aprítógép is megtalálható a piacon. Ezek egy vagy háromtengelyes megoldások, de az alapelvük hasonló. Egy vagy két tengelyre, tengelyenként 3-4 kést szerelnek, amelyek a darabolást végzik. A meghajtást illetően különböző megoldásokat találunk, amelyet főként a gép mobilitásának igénye határoz 
meg. A fürésztelepeken a hulladék darabolására használják a gépet., Itt általában villamos motorral hajtott gépekkel találkozhatunk, mivel nem szükséges a gép helyének változtatása.. A kisméretü ágak aprításra, valamint a bokros területek tisztítására a kis, kétütemü motoros meghajtású gépek jelentenek megoldást, mivel akár egy autó utánfutójára is szerelhetők, így könnyen szállíthatók. Az erdőkitermelésben, gyérítő vágások, vagy hasonló jellegü nagyobb feladatok elvégzésére traktor meghajtású gépeket alkalmaznak.

Egyes ágaprító gépeknél az ágakat egy külön előtoló szerkezet juttatja a kések közé. A két késtartó tengelyes megoldás esetében ezt az előtoló mozgást a geometriai felépítés biztosítja, mivel miután a kések elérték a fát, nem csak elnyírják, hanem amíg le nem válik a leválasztandó ág vég, addig a teljes ágat behúzódik. Így nincs szükség előtoló szerkezetre, ami tovább egyszerüsíti a gép felépítésétt.

\section{Az ágaprító gép bemutatása}

\subsection{A tervezési feladat bemenő adatai}

A fenti konstrukciók közül egy traktor meghajtású, háromtengelyű (két késtartó tengellyel rendelkező) gépet választottunk a tervezés kiinduló pontjaként , alapul véve, hogy a szükséges fogaskerekek rendelkezésünkre állnak, valamint a meghajtást biztosító erőgép egy UTB 445dt típusú traktor. További lényeges szempont amivel a tervezés során számolnunk kell,, az egyszerü javíthatóság, vagyis minél több szabványos elem használata, a gyors cserélhetőség biztosítására.

A gép hajtótengelye és az első meghajtott tengely között a fogaskerekek áttételi aránya miatt lecsökken a fordulatszám, a meghajtott (második) tengely pedig átadja a forgást a harmadiknak. Az utóbbi két tengelyre kések vannak rögzítve, amelyek egymással szembe fordulnak el és a vágás a két szembenálló kés közti rés csökkenése révén valósul meg.

Az aprítógépet egy szabványos (TLT) bordástengely segítségével hajtjuk meg, amelyet a traktor TLT csonkjához csatolunk egy kardántengely segítségével. Jelen esetben egy 1987-es UTB 445dt - típusú traktor adatait használtuk fel a méretezéshez, amelyben egy D115 típusú motor van. A motor 1967 fordulat/perc fordulatszámánál a teljesítmény leadó tengely 540 fordulat/perc fordulatszámmal forog. A motor legnagyobb nyomatéka 1500 fordulat/percnél 146,11 Nm. Ennél a fordulatnál a TLT-tengely 411,79 fordulat/perc sebességgel forog. [1]

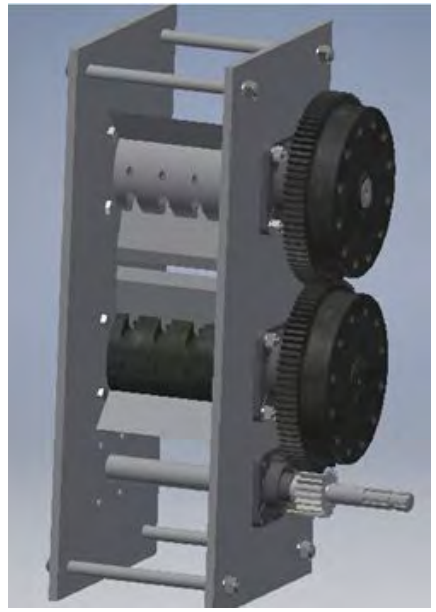

1. ábra. Ágapritó gép elemeinek összeszerelési vázlata

\subsection{A gép felépítése}

\subsubsection{A gép váza}

A gép vázát két $16 \mathrm{~mm}$ vastag OL50 anyagú lemez és az ezeket összekötő rögzítőcsavarok alkotják. A lapok mérete 480mm × $980 \mathrm{~mm}$. A lemezeken lévő furatokat nagy pontossággal kell kivitelezni, mivel a fogaskerekek tengelytávját a csapágyházak pontos elhelyezése határozza meg A csapágyházakat DIN7968 típusú illesztőcsavarokkal rögzítjük a lemezre. [2]

\subsubsection{A bordástengely}

A bordástengely ellenőrzése felületi nyomásra történik, a maximális nyomatékra.. A szerelés során az illesztett alkatrész nem mozog (a kardántengely nem mozdul el a bordástengelyen működés közben), az üzem jellegét pedig dinamikusnak vesszük, mivel ez a legkedvezőtlenebb eset. Jelen esetben a megengedett felületi nyomás a bordák oldalán $30-50 \mathrm{~N} / \mathrm{mm}^{2}$. [3]

A megengedett palástnyomást véve a bordáskötés által átvihető maximális csavarónyomaték:

$$
\begin{aligned}
& T=0.75 \cdot \psi \cdot\left(\frac{D-d}{2}-2 \cdot f\right) \cdot l \cdot r k \cdot z \cdot p m e g \\
& T=526.246 \mathrm{Nm}
\end{aligned}
$$

A képletben szereplő mennyiségek értelme a következő: - 0,75-el edzés után köszörüljük, a jobb éltartam elérése érdekében. $\Psi$ - a dinamikus tényező, D - külső átmérő, d - belső átmérő, f - a bordák lesarkításai, l - a bordák hosszúsága, rk - a közepes sugár, z - a bordaszám, pmeg - pedig megengedett felületi nyomás a lökésszerű igény- 
bevételre vonatkozó, nem edzett felületű bordára, amikor a kötés nem mozdul el. [3]

A bordáskötés a fenti számítások alapján megfelel az igénybevételnek.

\subsubsection{Késtartó tengelyek}

A tengely C45 jelü,- nemesíthető acélból készül. A második tengelyre egy reteszkötéssel van rögzítve a 78 fogú fogaskerék, amelyet a tengely végéből egy M14-es csavar rögzít a helyére egy alátét segítségével. A tengelyben három egymástól $120^{\circ}$-ra elhelyezett $13 \mathrm{~mm}$ széles $50 \mathrm{~mm}$ mély bemarás található, amelybe M12-es csavarokkal rögzítve lesznek a kések.

A harmadik tengely hasonló felépítésű, kizárólag a marások iránya változik, mivel ennek a tengelynek fordított a forgásiránya.

A tengelyek csavaró nyomatékkal szembeni méretellenőrzését a tengelyvégek méretének ellenőrzésével végeztük, és az eredmények alapján szilárdságtanilag ellenállnak az igénybevételnek. [4]

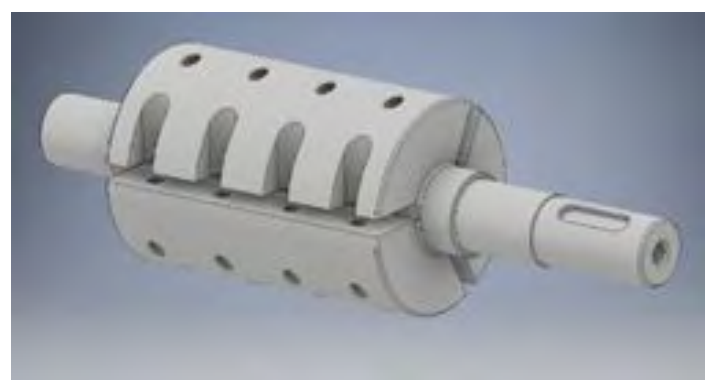

2. ábra. Késtartó tengely

\subsubsection{Kések}

A kések magas széntartalmú, edzhető és nemesíthető acélból készülnek, 55-57 HRC-re edzve. A $12 \mathrm{~mm}$ vastag $250 \mathrm{~mm}$ hosszú és $132.5 \mathrm{~mm}$ széles késeket egyenként a tengelyekbe mart $13 \mathrm{~mm}$ széles résekbe helyezve egyenként négy darab M12 8.8 vagy nagyobb szilárdsági osztályú finommenetes csavarral rögzítjük a tengelybe. A késekben minden csavarnak egy $13 \mathrm{~mm}$ széles és $20 \mathrm{~mm}$



3. ábra. Egy kés geometriai kialakítása hosszú hornyot kell marni, annak érdekében, hogy az élezések után állítható legyen a kések közti rés. A kések pontos beállítása érdekében a kések alsó részen állítócsavaroknak készítünk helyet.

A kés élét 30 fokos szögben készítjük el és köszörülve, valamint edzve lesznek a jó éltartam érdekében.

\subsubsection{Reteszek}

A reteszkötések méretezése általában felületi nyomás alapján történik. [5]

A - típusú reteszeket használunk, amely a DIN 6885 szabvány szerint készülnek. [6] A retesz szükséges hosszát az

$$
l=\frac{2 \cdot M t}{(d+h-t 1) \cdot(h-t 1) \cdot z \cdot p m e g}
$$

$$
l f=l+b
$$

képlettel határozhatjuk meg, ahol: l - az A típusú retesz párhuzamos oldalának hossza, Mt - a bemenő csavaró nyomaték, d - a tengely átmérője, h - a retesz magassága, $\mathrm{z}$ - a reteszek száma, t1- a tengelyhorony mélysége, pmeg- pedig a hőkezelt acél agy megengedett felületi nyomása.

A felületi nyomás esetén a lehető legkedvezőtlenebb esetet választottuk a megadott értékintervallumból, mivel így biztosan megfelel majd a terhelésnek. Az lf - érték az a minimális hossz, ami szükséges a retesznek, a végein található kerekítéssel együtt, $\mathrm{a}$ b - pedig a retesz szélessége. a táblázatból az lf - értéknél nagyobb, ehhez a legközelebb álló értéket választjuk. A számítások eredménye alapján a következő jelű reteszeket választjuk:, a bordás tengelybe DIN 6885 - A10 x $8 \times 32$ - C45 K, a késtartó tengelyekbe pedig DIN 6885 - A16 x 10 x 63 -C45 K. [7]

\subsubsection{Csapágyazás}

A tengelyekre radiális erő hat, ezért radiális csapágyakat alkalmaztunk. A már létező fogaskerekek furatának átmérőjénél nagyobb átmérőjű csapágy- belső átmérőt kell válasszunk, hogy a fogaskerék a tengelyen megjelenő vállra támaszkodjon. A fogaskerekek belső átmérője 52,3 mm, az ehhez legközelebb álló csapágy átmérő az 55 mm-es átmérő.

A csapágyházakat a legtöbb gépnél az oldallapokban alakítják ki, így az oldallapnak ezen a részen legalább $28 \mathrm{~mm}$ vastagságúnak kellene lennie, és jó minőségű anyagból kellene készülnie. Ezt legkönnyebben öntéssel lehetne elérni. Viszont ez nagyon költséges megoldás, mivel ha meghibásodik a csapágy és az oldallapban elde- 


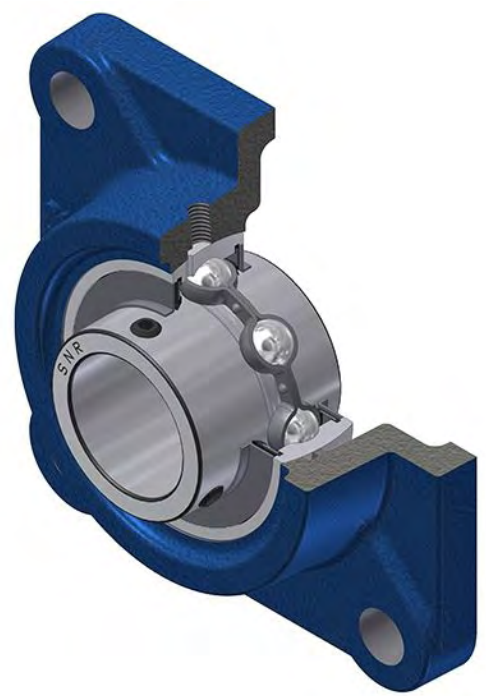

4. ábra. UCF típusú csapágyegység. [8]

formálódik a csapágyház, akkor a teljes oldallapot cserélni kell, ami ugyancsak költséges lenne. Ezért UCF típusú csapágyházakat alkalmazunk. Az UCF csapágyházak négy csavarral rögzíthetők az oldallaphoz. A csapágyak radiális terhelése a csavarokban nyírási igénybevételként jelentkezik.

A választott csapágyházak másik előnye abban áll, hogy megengedi a külső gyürü elfordulását a terhelés függvényében, így nem feszíti működés közben a csapágyat. Ezzel a megoldással a gyártási pontatlanságok kiküszöbölhetők, könnyen cserélhető és egyszerüen javítható, valamint a csapágy használata során a kenést is lehetővé teszi.

\subsubsection{Fogaskerekek}

A meglévő fogaskerekek $\mathrm{m}=4.25 \mathrm{~mm}$-es modullal rendelkeznek és teherbírásra való méretellenőrzés során megfeleltek a fogtőhajlítási illetve fogfelületi igénybevételeknek.

\subsubsection{Borító elemek}

A gép működése közbeni balesetek megelőzése érdekében a gépet borítóelemekkel látjuk el, amelyeket $2 \mathrm{~mm}$ vastag lemezekből készítünk. A borító elemekkel a munkást védjük, a szerkezet mozgó (forgásban) levő elemeitől, valamint a vágások során letöredező faforgácstól. A fogaskerekeket is burkoljuk, valamint a géphez egy tölcsért csatolunk, ami darabolás közben megtartja a fadarabot.

\section{Következtetések}

A fent bemutatott ágaprító berendezés nagy teljesítményü, masszív szerkezet, amely ágak és kis átmérővel rendelkező fadarabok feldarabolásának jelentős gyorsítását és egyszerüsítését segíti elő. A szabványos, valamint a meglévőelemek használata jelentősen csökkenti a költségeket, ugyanakkor a hosszas használat utáni elkopott elemek cseréjét is egyszerüsíti.

A méretellenőrző számítások eredményei alapján kijelenthetjük, hogy a szerkezeti elemek megbírják a terhelést, habár a fa feldarabolásához szükséges erőt csak becsülni tudtuk; ezt majd a gép elkészítése után tudjuk kisérletek alapján lemérni. A gépet hajtó erőgép által kifejthető maximális nyomatékot minden elem megbírja.

Mivel a gép forgó (mozgó) alkatrészei veszélyt jelentenek a gépkezelő munkás számára, így a gépet borítólemezekkel látjuk el. A gépet egy etető tölcsérrel látjuk el, ami megtartja a darabokat a vágás során.

\section{Szakirodalmi hivatkozások}

[1] Universal, D115. (letöltve: 2019.02.21.)

https://www.scribd.com/document/228945425/ Reglaje-Motor-D115-U445-550.

[2] DIN 7968: Hexagon fit bolts for steel structures. 2007.

[3] Zsáry Á.: Tengely - agy kötések. Bordás tengelykötések. In: Gépelemek I. (Szerk.: Zsáry Á.). Nemzeti Tankönyvkiadó Rt., Budapest, 1999. 213-216.

[4] Antal A., Pop D., Oltean I. E. F.: Elemente constructive privind proiectarea arborilor. Capete de arboare cilindrice. In: Reductoare (Szerk.: Antal A.). Lito UTCN, Cluj Napoca, 1994. 141-143

[5] Antal B., Tolvaly-Rosca F.: Gépelemek 1, Egyetemi jegyzet, Sapientia Erdélyi Magyar Tudományegyetem, 2008.

[6] DIN 6885: Reteszkötések, 2008.

[7] Frischherz A., Dax W., Gundelfinger K.: Gépelemek. Reteszek. In: Fémtechnológiai táblázatok. (Szerk.: Frischherz A.). B + V Könyvkiadó KFt., 1997. 206.

[8] NTN-SNR Prémium csapágyak webáruháza: UCF 308 (letöltve: 2019. 02.20.).

https://www.ntnsnr.hu/ucf308_30067 